\title{
Unable to Stop Inequality from Rising: Evidence from Romania
}

\author{
Paul Dobrescu and Flavia Durach
}

\section{Introduction}

In today's world, there are no fundamental issues, from development to social mobility, from migration to social inclusion, separate from the process of growing inequality. The process is not stagnant; the economic crisis in 2008-2009 deepened inequalities instead of mitigating them. In recent years, inequality surfaced in the shape of social unrest, protest movements and unpredictable voting behaviour. In this respect, the year 2016 was a turning point. Brexit, Trump's election as president, the ascent of populism - all these events were the indirect result of public discontent, exacerbated by inequality. Economic inequality needs to be correlated with its social consequences, thus pushing the issue onto the political agenda. In this vein, the editors of the volume After Piketty, The Agenda for Economics and Inequality note that when Piketty's ground-breaking work was published in 2014, its predictions were questioned: "maybe, but also maybe not" (DeLong et al. 2017, p. 2). Three years have passed, and during this time, facts piled up to support the French author's view. "And so, Piketty's analytical political economic case looks to us to have been greatly strengthened by Trump's presidential election victory" (DeLong et al. 2017, p. 2). The conclusion is unequivocal: "If Piketty s book was distastefully radical before, now it looks vitally necessary" (DeLong et al. 2017, p. 4).

The World Economic Forum 2018, in Davos, discussed international stability as a recurrent theme. When a forum of such magnitude expresses concerns regarding the

This chapter has been prepared with financial support granted in the project "State of the Nation. Designing an innovative instrument for evidence-based policy-making" (SIPOCA 11, MySMIS 118305), which is co-financed by the European Social Fund through the Operational Programme Administrative Capacity 2014-2020.

P. Dobrescu $(\bowtie) \cdot$ F. Durach $(\varangle)$

National University of Political Studies and Public Administration, Bucharest, Romania e-mail: paul.dobrescu@ comunicare.ro; flavia.durach@ comunicare.ro 
stability of today's world, it implies that great threats are emerging. What are those threats, to be more precise? Branco Milanovic (2016) provides an explanation. The author shows that global inequality between nations has a similar evolution to the inequality within nations.

By relating to the aforementioned ways of understanding inequality, this chapter investigates the different faces of inequality within Romania, with an emphasis on regional disparities. Furthermore, we aim to pinpoint the country's ranking in its geographic region (Central and Eastern Europe) as reflected by some key indicators of development. A secondary focus of our study will be on the Romanian citizens' perceptions of inequality, using data from a representative public opinion survey conducted in the project The State of the nation. The development of an innovative instrument for grounding the development of public policies in Romania.

\section{Towards a Second "Gilded Age": Trends in National and Global Inequality}

Thomas Piketty's highly acclaimed work Capital in the 21st Century (2014) provides a historical analysis of the evolution of income and wealth dating back to the eighteenth century. His empirical findings are troubling: The turn of the century witnessed a return to the high levels of inequality experienced in darker, earlier times in human history. The author shows that cyclicity is an intrinsic feature of inequality, defined as the gap between capital's share and labour's share of the national income. More precisely, capital's share ranged between $35-40 \%$ between the late 18th through the 19th centuries, falling to $25-30 \%$ in the mid-twentieth century and increasing again to $25-30 \%$ in the late twentieth and early twenty-first centuries (Piketty 2014, p. 200).

Inequality tends to increase or decrease according to the variations of the economy. Capital in the twenty-first Century postulates that when the return on capital is greater than national growth, it tends to accumulate faster, make inherited wealth more relevant, and exacerbate inequalities. As we are currently witnessing a period of reduced growth (in economic and demographic terms), capital gains significant momentum to the detriment of labour (Piketty 2014, p. 166). In other words, we are living in an age when capital is making its comeback. We are heading to a second "gilded age", dominated by wealth (especially inherited wealth) to the detriment of income, an age in which the owners of capital will have the power to shape the course of economy and politics while skyrocketing differences in income will lead to a growing divergence between social groups.

Inequality within nations (described above) is only one side of the coin; to flip the coin means looking at inequalities between countries. In this vein, Milanovic (2016, p. 20) argues that the winners of globalisation are the "global middle class located mostly in China and other countries from resurgent Asia, whereas the main losers are the lower middle classes of the rich world". To justify his bold statement, the author 
measures the relative gain in real household per capita income between 1988 and 2008 at different points of the global income distribution, noting that real income gains were greatest among people around the 50th percentile of the global income distribution (most of them coming from emerging Asian economies), and among the richest $1 \%$. The lowest gains came for the 80th percentile globally, meaning the lower middle class of the rich world (Milanovic 2016, p. 11). Inequality within countries is likely to intensify:

The great middle-class squeeze, driven by the forces of automation and globalization, is not at an end. This squeeze will in turn further polarize western societies into two groups: a very successful and rich class at the top, and a much larger group of people whose jobs will entail servicing the rich class in occupations where human labour cannot be replaced by robots. (Milanovic 2016, pp. 214-215)

\section{The Economic and Social Consequences of Inequality}

There is broad debate in the literature whether inequality is good or bad. That depends on what we have in mind. There is a normal, positive inequality, which stimulates growth by enforcing a merits-based hierarchy of success. However, in this chapter we focus on negative, destabilizing or malign levels of inequality. The comments of IMF director Christine Lagarde are a perfect illustration of our point:

\footnotetext{
Our research shows that, if you lift the income share of the poor and middle class by $1 \%$ point, then GDP growth increases by as much as $0.38 \%$ points in a country over five years. By contrast, if you lift the income share of the rich by 1\% point, then GDP growth decreases by $0.08 \%$ points. One possible explanation is that the rich spend a lower fraction of their incomes, which could reduce aggregate demand and undermine growth. In other words, our findings suggest that - contrary to conventional wisdom - the benefits of higher income are trickling up, not down. This, of course, shows that the poor and the middle class are the main engines of growth. Unfortunately, these engines have been stalling. (Lagarde 2015)
}

Inequality has broad social consequences, resulting in a higher or lower public tolerance of this phenomenon. In social contexts where citizens have a real possibility to advance through personal merit and hard work, tolerance towards inequality is higher, whereas in societies or social groups where opportunities for social mobility are fewer, the tolerance is significantly lower.

Scholars link inequality to intergenerational mobility and social mobility (Ermisch et al. 2012; Krueger 2012; Jerrim and Macmillan 2015). Furthermore, inequality threatens equal opportunities, and increases the importance of inherited fortune (Piketty 2014). According to the Great Gatsby Curve (Krueger 2012), unequal states have less economic mobility than their counterparts. In such states, the poorest tend to limit their life aspirations since their efforts prove to be in vein in the absence of inherited wealth (Dalton et al. 2015).

The figures are mirrored by the public perception of inequality. The US, for instance, where inequality is on the rise, is witnessing, for the first time in history, the demise of the American dream. The recent work of Graham (2017) questioned Americans on their perceptions of the future and on how hard work could help them 
advance on the social ladder. Results suggest that Americans are no longer tolerant towards inequality. This striking result is the consequence of a lack of faith in the American dream-achieving success through a combination of hard work, vision and good luck. In 2016, only 38\% of Americans thought their children would be better off than they are. This change is especially valid for poor citizens, whereas the rich continue to believe that hard work and education will allow them to prosper more than previous generations.

We are experiencing a time when excessive inequality surfaces in the shape of social turmoil. Few realize that people's confidence in the concept of upward mobility, based on hard work and high performance of talent (going "from rags to riches", the quintessence of the American dream) fuels capitalism. Excessive inequality limits upward mobility while consolidating the dominance of the select few, based on inherited wealth instead of merit. Inequality makes social structures more rigid and directly affects the legitimacy of the establishment. "That's the problem with increased inequality - it diminishes upward mobility. It makes the top and bottom rungs of the ladder "stickier"- harder to move up and harder to lose your place at the top" (Obama 2016).

During the International Conference Centesimus annus pro Pontifice Foundation, Pope Francis stated that "an economy of exclusion and inequality" produces an evergrowing number of "the disenfranchised and those discarded as unproductive and useless". By emphasizing the need to change this reality, the pontiff called for "new models of economic progress" which are "more clearly directed to the universal common good, inclusion and integral development, the creation of labour and investment in human resources" (Pope Francis 2016).

\section{Inequality in Romania}

The second half of this chapter is dedicated to analyzing inequality in Romania and its impact on the country's development. By means of secondary data analysis, we use institutional sources (such as Eurostat, the National Institute of Statistics in Romania, and the National Bank) to assess the level of economic inequality from multiple perspectives and identify the main drivers of inequality. Lastly, we discuss the consequences of severe inequality on the inclusive, long-term development of Romania. Following T. Piketty's approach, we discuss inequality, among others, through the ratio between the capital share and the labor share of the national income. We explore the consequences at a societal level by analyzing the distribution and redistribution processes. Lastly, we address soft issues related to the public perception of inequality.

The period of analysis is between 1990 (following the fall of the communist regime in Romania) and 2017 (depending on the data availability at the time of writing this chapter). Where feasible and relevant for our argument, we favor a comparative approach to other countries in Central and Eastern Europe as well as to the EU average. We define Romania's peer group as consisting of Hungary, Bulgaria 
and Poland based on geographical proximity (Hungary, Bulgaria), a similar level of development (Bulgaria) and similarity in size (Poland).

The analysis of inequality in Romania in the last three decades must take into consideration the country's transition to a democracy and the market economy, a transition challenged by the global competition and circulation of foreign capital, as core features of globalization. The scale of Romania's transformation led not only to positive change but also to contradictions and tension. Rising inequality distinguishes itself as a serious issue given the complexity of its causes and the magnitude of its consequences.

Before debating the distribution of income, we must discuss economic performance in terms of GDP and national income. What matters here is the size of the "pie"-is the shared wealth large enough to satisfy both capital owners and workers? We will depict Romania's evolution in terms of GDP and national income, followed by a comparison with other countries in its peer group. From this point of view, the process of distribution and redistribution of the newly created value in an economy has strategic importance.

Data show that Romania's GDP had many fluctuations in the last 30 years. The country experienced two sharp economic declines in this recent history: the first after the fall of the communist regime in 1989, when the economy contracted by $40 \%$ in only 3 years (from 42.105 billion US dollars in 1989 to 25.122 billion US dollars in 1992). It took almost a decade to reach the GDP from 1989 again. The second crash took place after the 2008-2009 crisis, when the GDP decreased by $19 \%$ in just 1 year, from 208.192 billion US\$ in 2008 to 167.423 billion US\$. Once again, recovery was slow and hard: it took 6 years to reach a similar GDP level (US $\$ 199.493$ billion in 2014), only to experience another steep decrease the following year (World Bank Database, accessed 2017, GDP in current US\$). The lengthy recovery periods suggest a lack of robustness of Romania's economy and a low resilience to economic shocks.

Many things can be said about Romania's transition to a market economy; what is of the greatest importance is that during those years, everybody talked about reform and modernization while the country's economy plummeted. While development cannot be reduced to economic growth, development cannot happen in its absence either. Thirty years later, one can see that the mantra of reform and modernization failed to ensure sustainable and inclusive progress as the gaps between Romania and other countries in Western, Central and Eastern Europe widened.

When turning to Eurostat data, we see that in 1989, Romania's GDP was US $\$ 38.995$ billion and Poland's was US\$65.978 billion (World Bank Database, GDP in current US\$). Hence, Romania's GDP was approximately two-thirds of Poland's GDP while having half its population. Later, in 2000, Romania's GDP was approximately the same as in 1990 (US $\$ 37.439$ billion) while the Polish one had grown 2.6 times (US $\$ 171.886$ billion). During that decade, Romania had failed to grow as an economic power while Poland had amplified its economy 2.6 times. After the year 2000, Poland managed to sustain its growth. Between 2000 and 2016, its GDP rose 2.7 times, reaching the impressive amount of US $\$ 471.364$ billion (7.1 times greater than in 1990). During the same interval of 1990-2016, Romania's GDP rose only 
4.8 times. Furthermore, Poland managed to strive despite the economic crisis, thus proving its capacity for reform instead of de-industrialization (in the same vein, also see Zamfir 2017).

A decade of EU membership has failed to close the gaps between Romania and other countries. According to the latest Eurostat data, Romania's real GDP/capita in 2016 was EUR 7700 compared to EUR 27,000 (EU28 average). Romania's GDP/capita is significantly lower than its peers in CEE: 11,200 EU in Poland and 11,300 in Hungary. Bulgaria is the only EU member state with a lower GDP/capita than Romania (Eurostat, tsdec100).

The GDP is not the only indicator of a nation's economic prosperity. One must analyze the national income as well, meaning the sum of all income available to the residents of a given country in a given year regardless of the legal classification of that income (Piketty 2014). The national income differs from the GDP in two ways. Firstly, to calculate the national income, the depreciation of capital must be subtracted from the GDP. Secondly, one must add net income received from abroad and subtract net income paid to foreigners, depending on each country's situation (Piketty 2014). In Romania's case, the net national income is significantly lower than its GDP. In 2014, Romania had a GDP of EUR 150,357 million and a net national income of EUR 121,452 million, a modest improvement since EU accession (when the net national income was EUR 100,925 million) (Eurostat, tsdec230 and nama_10_gdp).

As suggested by the data above, Romania has a modest national wealth to distribute between capital and labor. Since this chapter is devoted to the topic of inequality and ways to reduce it, we must emphasize Romania's handicap of having a smaller "pie" to share than other countries in the region. This disadvantage must be taken into consideration and, where possible, corrected through distribution between capital and labor. Is the distribution process conceived and implemented in order to correct, or at least ameliorate this economic handicap of Romania? We would say the contrary, as Table 1 shows.

In 2016, the labor share was as low as $41.6 \%$. In the last 17 years, the labor share in Romania was the greatest in 2001 (52.5\%) and the lowest in 39.9\% (in 2013). That means that the main cost of the economic crisis was paid by labor. The labor-capital share ratio lays the conditions for the perfect storm. For example, in 2016, 38.8\% of Romania's population is at risk of poverty (Eurostat, t2020_50). Bulgaria is the only EU member to have a larger share of its population at risk of social exclusion. The EU average is of $23.5 \%$. We would also like to draw attention to the fact that in 2016 , the richest $20 \%$ of Romanian citizens had an income 7.2 times greater than the poorest 20\%; a ratio higher than in other CEE countries such as Poland (4.8) and Hungary (4.3) (Eurostat, ilc_di11).

The third category of factors influencing social inequality is related to economic redistribution (e.g. government expenditure for education, health, public infrastructure, etc.). Given the economic context in Romania (low GDP, unequal distribution between capital and labor), public investments in the aforementioned areas can only be deficient. In the logic of our argument, let us imagine a hypothetical situation in which the wages of two individuals or groups are sensibly different. In the public 
Table 1 Labor share in the net national income

\begin{tabular}{l|l|l|l|l|l}
\hline \multicolumn{2}{l}{ Labor share in the national income } \\
\hline & USA (\%) & Germany (\%) & France $(\%)$ & UK $(\%)$ & Romania (\%) \\
\hline 2000 & 66 & 64 & 58 & 60 & 50 \\
\hline 2007 & 64 & 56 & 59 & 60 & 46 \\
\hline 2008 & 65 & 58 & 60 & 60 & 48 \\
\hline 2009 & 64 & 60 & 62 & 62 & 47 \\
\hline 2010 & 63 & 59 & 62 & 60 & 44 \\
\hline 2011 & 62 & 58 & 61 & 58 & 41 \\
\hline 2012 & 61 & 60 & 62 & 59 & 41 \\
\hline 2014 & 61 & 60 & 63 & 60 & 40 \\
\hline 2016 & 63.8 & 60.1 & 62.5 & 59.7 & 39.7 \\
\hline
\end{tabular}

Source: Georgescu, F., First Deputy Governor, National Bank of Romania (2017). Retrieved from: http://www.bnr.ro/Prezentari-si-interviuri\%2D\%2D1332.aspx?fld_issue_year=2017, accessed November 11th, 2017

system of education, the state delivers a free adequate education for everyone, irrespective of income. From this perspective, the education system not only channels the young generation's full potential but also enforces equal opportunities for all members of society. A similar logic of state intervention can be applied to infrastructure and health services as well.

Instead of reducing inequality and stimulating inclusive development, the current low levels of government expenditure aggravate gaps and threaten Romania's development. As far as public spending is concerned, Romania is last in its region as well as in the EU (Fig. 1).

Government expenditure includes the current spending and investment by central government and local authorities, directed towards providing social goods and services and serving the needs of the community. In 2016, total government expenditure in Romania rose to $34.7 \%$ of the GDP whereas the EU average was $46.6 \%$ (12 pp. higher). Romania's peer group performed better, with Hungary leading the way $(47.5 \%)$, followed by Poland $(41.3 \%)$ and Bulgaria $(35.5 \%)$.

Data are particularly worrying since the state is the main provider of basic services and investments in vital sectors such as health, education and infrastructure. Via redistribution, the state has the ability to tackle inequality and foster development. The public health and education systems, which should guarantee high-quality services for all, suffer equally from insufficient funding. In Romania, the health sector receives the least financial resources compared to the EU average and the peer group. In 2015, the Romanian government allocated $4.2 \%$ to health compared to 7.2\% the EU average, 5.5\% in Bulgaria, 5.3\% in Hungary, and 4.7\% in Poland. As far as education is concerned, Romanian government spending is significantly lower $(3.1 \%)$ than the EU average (4.9\%). It is worth mentioning that in the peer group, Poland and Hungary make education a top national priority by investing more than the EU average in this area (5.2\% in both cases). 


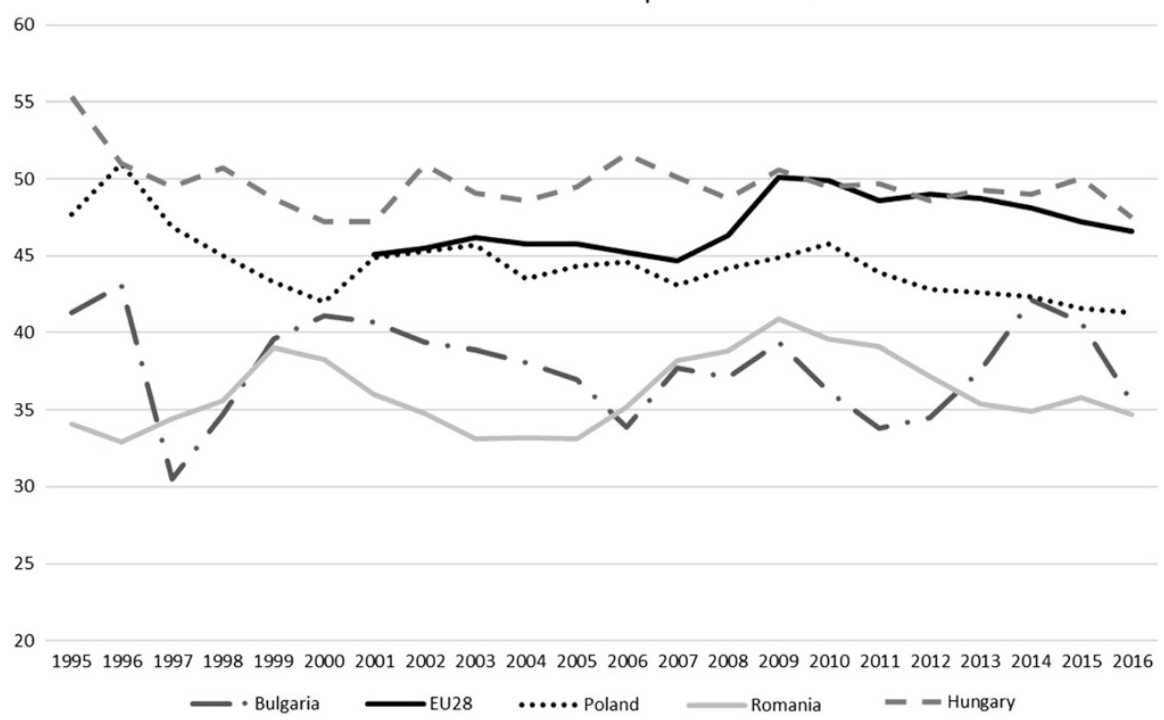

Fig. 1 Government expenditure as \% of the GDP. Source: Eurostat, Government revenue, expenditure and main aggregates (gov_10a_main), retrieved from: http://appsso.eurostat.ec.europa.eu/ nui/show.do?dataset=gov_10a_main\&lang=en, accessed November 15th, 2017

To have a broader perspective on the financing mechanisms, we must add that governmental revenues do not result directly from the size of the GDP; they are dependent on taxation. Romania's tax revenues are $15 \mathrm{pp}$. lower than the EU average (Eurostat, gov_10a_main). On average, tax revenues in the EU added up to $44.9 \%$ of the GDP in 2016 while in Romania, they equal $31.7 \%$ of the GDP. Our country collects the smallest tax revenues in its peer group (Hungary $46.2 \%$, Poland $39.1 \%$, Bulgaria 34.1\%).

In Romania, high inequality negatively affects cohesion and solidarity, especially when regional differences are considered. Since the 1990s, when Romania transitioned to a market economy, the difference between its wealthiest and poorest region increased constantly. In 1995, Bucuresti-Ilfov (the richest region) had a GDP 1.6 times higher than the poorest region (South-West Oltenia). In 2007, when Romania became an EU member, the difference was 3. In 2014, Bucuresti-Ilfov had a GDP 3.7 higher than South-West Oltenia, suggesting the failure of the cohesion policies (National Institute of Statistics in Romania, Regional gross domestic product (RGDP)—current prices calculated according CANE Rev.1 (1995-2008) \& CANE Rev.2-ESA 2010 (2000-2014).

Romania's regions contribute to the national GDP in an unbalanced manner. In 2000, Bucuresti-Ilfov accounted for $23 \%$ of the GDP whereas the other regions accounted for from 9 to $12 \%$ (Fig. 2). Following the economic crisis, the contribution of each region to the GDP stalled, decreased or rose very slightly. The notable 


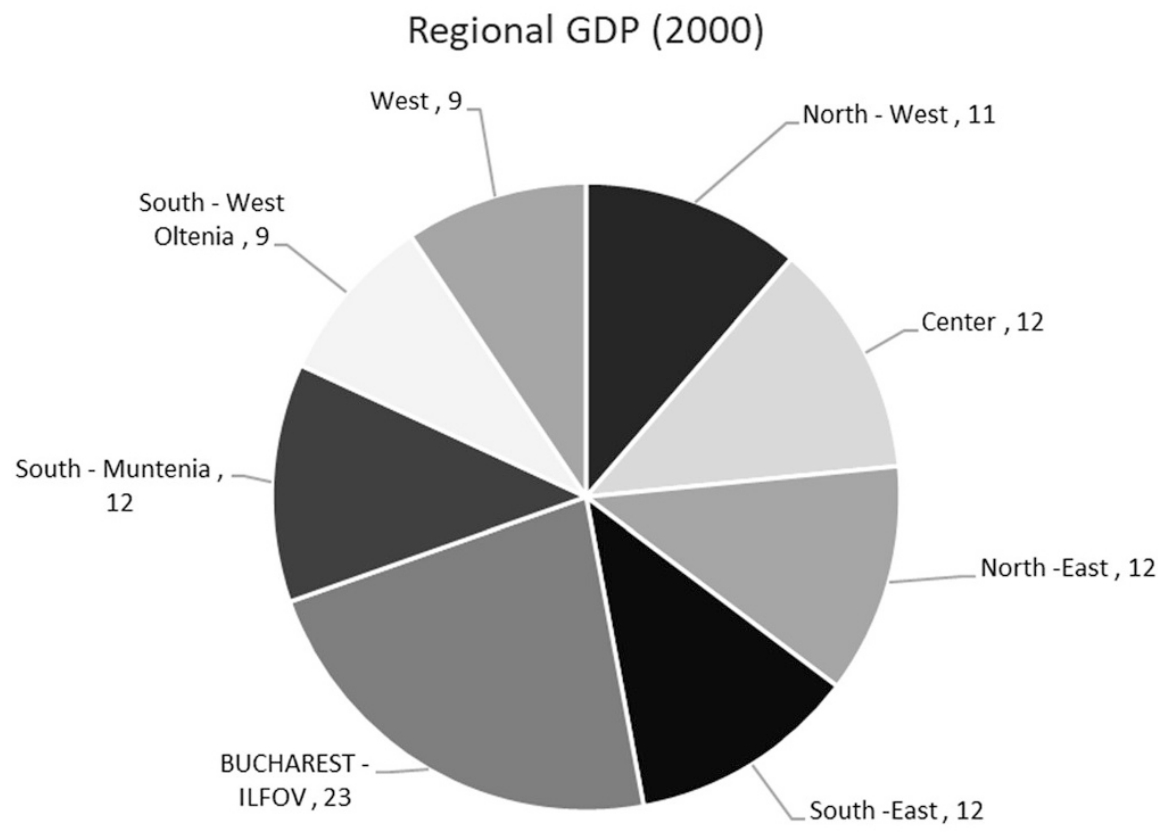

Fig. 2 The contribution of the NUTS2 regions to the national GDP (\%)-Year 2000. Source: National Institutite of Statistics (Regional gross domestic product (RGDP) - current prices, calculated according CANE Rev.2-ESA 2010, authors' calculations. Retrieved from: statistici.insse.ro, accessed November 15th, 2017

exception is the region Bucureşti-Ilfov, whose contribution to the GDP rose by 4 pp., now accounting for from $23 \%$ to $27 \%$ of the national GDP (Fig. 3 ).

The hallmark of development should be closing the gaps in terms of economic performances between Romania's regions. Cohesion and even development form the backbone of any given national community. The gaps in economic development lead to a troubling accumulation of distrust and discontent.

Another persistent gap is the one between urban and rural areas. The GDP/capita of the rural areas is significantly lower. In 2007, the urban area had a GDP/capita 3.2 times higher than the rural area (EUR13,000 versus EUR4000). In 2014, we find the gap unchanged (EUR16,000 versus 5000) (Source: Eurostat, urt_10r_3gdp). The intermediate (small urban) segment shows more similarities to the rural area than to the urban one. Figures prove that the economic vitality is concentrated in and around Romania's large cities whereas the rest of the country remains significantly poorer.

With the aid of statistical data, we painted a portrait of inequality in Romania; however, public perceptions are equally important. How do regular citizens feel about inequality? Do they perceive Romania's development gaps? Some insights can be found in a recent survey contracted within the EU-funded project The State of the Nation. The development of an innovative instrument for grounding the development of public policies in Romania. The survey was conducted in September 2017 


\section{Regional GDP (2014)}

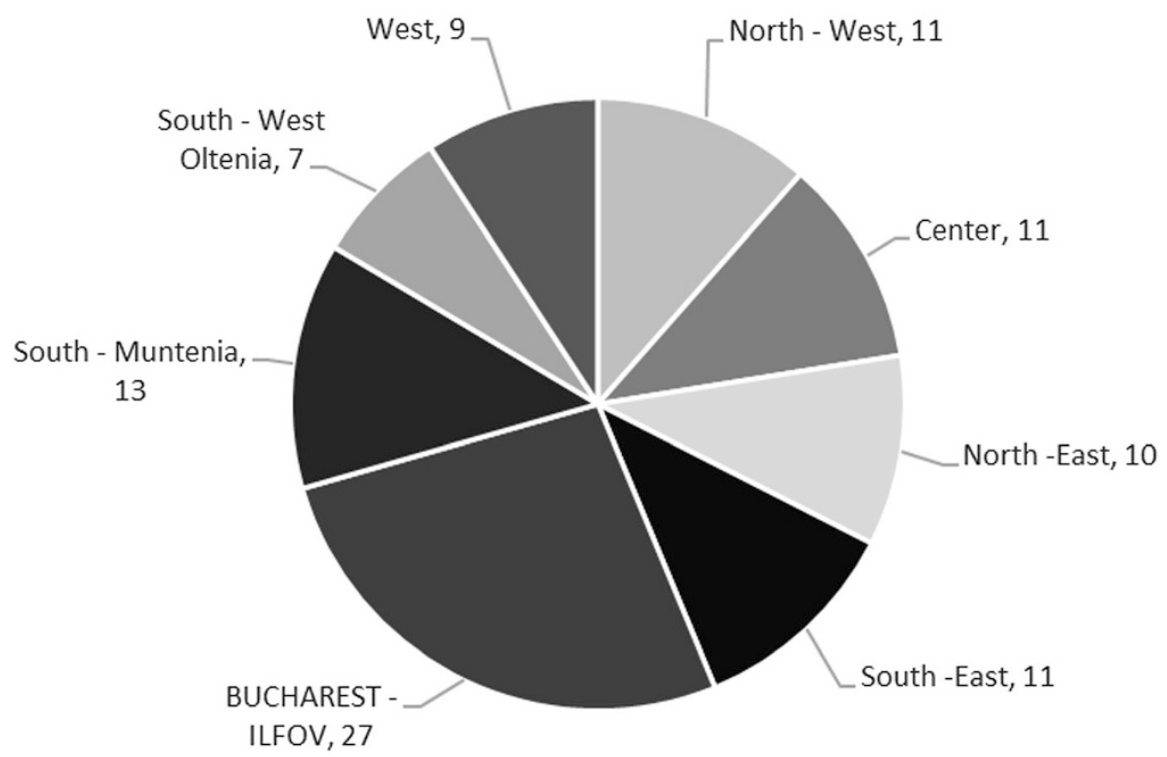

Fig. 3 National Institute of Statistics, The contribution of the NUTS2 regions to the national GDP (\%)—Year 2014. Source: INS (Regional gross domestic product (RGDP)—current prices, calculated according to CANE Rev.2-ESA 2010, authors' calculations. Retrieved from: statistici.insse.ro, accessed November 15th, 2017

on a representative sample of 1107 respondents. The majority of Romanians perceive strong inequalities between their country and others. The respondents feel their standard of living is worse than the standard of living of citizens from the developed EU countries $(82.2 \%)$ as well as other CEE countries $(76.9 \%)$. There are more Romanians who feel that EU membership improved Romania's economic situation to a small extent (47.9\%) than Romanians who believe that Romania's economy performs better after accession (44.3\%). These results mirror to some extent the actual data given that Romania's GDP decreased sharply shortly after accession (under the impact of the economic crisis) and recovered very slowly. Despite constant access to cohesion funds before and after the accession, the development gaps in Romania persist and citizens seem to be well aware of this, especially at the individual level. While $40.2 \%$ of respondents believe they have a better standard of living than the average person, $31.7 \%$ feel they are worse. The percentages remain almost unchanged when asked to think how EU membership impacted their standard of living (42.8\% "better" and 37.5\% "worse"). Lastly, we find it striking that Romanians lost hope as far as upward social mobility is concerned: $88.9 \%$ of respondents think it is difficult or extremely difficult for a person to achieve a higher social status today. 


\section{Inequality and Development in Romania: Worrying Trends}

As illustrated in the previous section, many scholars and public figures consider inequality bad for development. The former USA president Barack Obama (2016) emphasized that inequality makes vertical social mobility very difficult. Piketty (2014) warned us of the risk of the present devouring the future, and democracy losing its control over capitalism. Mervyn King (2016) wrote about "the paradox of policy - where policy measures that are desirable in the short term are diametrically opposite to those needed in the long term".

The evolution of inequality in Romania illustrates a similar truth: not only is there a risk of the present devouring the future, the mere idea of preparing for a better future has been blatantly ignored. During the last three decades, Romania's path for development has been hesitant and subjected to frequent shifts. Romania has become a country of contrasts and cleavages, in need of a vision for the future.

The issue at hand is not necessarily the complete lack of vision but building upon the wrong vision. The result? A regrettable delay of Romania's progress. One manifestation of this wrong vision is the belief that a country's evolution does not need to follow a centralizing strategy to ensure the macro balance. A recent report by the Research Institute for the Quality of Life in Romania (Zamfir 2017) emphasizes one fundamental weakness in the last 30 years: the false belief that social well-being is the result of economic growth. There was little understanding and little emphasis on the importance of going beyond the GDP. We agree that quality of life, as well as inclusive development, rely on economic performance; nevertheless, the best results can be achieved only with sustainable, reasonable and well thought-out public policies that draw on a country's priorities for development. Without these policies, life in Romania remains unsatisfactory despite its promising economic growth.

In the last 30 years, Romania has experienced moderate economic growth and, unfortunately, little development. By "development", we envisage a harmonizing process that brings social and economic issues together and provides a clear and unique vision of the economic and social life of a nation. We envisage a process that carefully considers Romania's potential for consumption, and adjusts its production to prevent unbalances in this fundamental economic relation. We will provide the reader with a few examples. Between 2007 and 2016, the GDP increased to 36\% while the number of individuals at risk of poverty and social exclusion decreased to only $18 \%$. Furthermore, the percentage of people in this situation is rose from $37.4 \%$ in 2015 to $38.8 \%$ in 2016 (Georgescu 2017). Another example shows that Romania exports unprocessed goods (in this case, cereals) and imports highly processed ones (in this case, meat) (National Institute of Statistics, EXP102D and EXP101E). This economic behavior is commonly seen in underdeveloped economies. Lastly, Romania undertook a massive deindustrialization only to make efforts to restart its industrial activity later; the new production units produce goods with small added value. Romania is falling deeper and deeper into what is called in the literature the 
medium income trap. The country is paving the road in the medium development range instead of aiming towards becoming a highly developed country.

A coherent and inclusive vision is a state attribute; only the state can act on behalf of the whole. We consider a state should be entrepreneurial and intelligent. Consequently, we believe the state should rethink its role and responsibilities. "The relationship between states and economic activity is constitutive not incidental" (Calhoon 2015, 219). The state should act in the realm of strategic thinking.

In its quest for development, Romania is pressured by its demographic evolution. The total fertility rate (average of 1.6 children per woman in 2015) is significantly lower than the minimum need for a preserving its population (2.2 children) (Eurostat, demo_frate). Furthermore, Romania has the highest number of migrants in Europe. In 2016, 207,578 people left the country (National Institute of Statistics, accessed 2018, POP320A), contributing to the three million migrants that fled Romania in the last 30 years. We can anticipate scarcity in the labor force, especially in some regions; this situation will affect labor productivity and development.

Other factors can be considered as well. As far as education is concerned, Romania experienced a decrease, to approximately $91 \%$, in enrolment rates for primary, lower secondary and upper secondary levels of education (UNESCO, Gross enrolment rates by level of education) and the highest rate of early school leavers in the EU (18.6\% in 2016-Eurostat, edat_lfse_30). Coupled with a low healthy life expectancy at the age of 65 (Eurostat, hlth_hlye_h and hlth_hlye), we see that Romania is facing a demographic crisis.

What seemed to be a temporary solution for some (working abroad for a while then returning home) became a more permanent one (leaving without wanting to return). The demographic crisis will soon happen, and when it does, it will affect the functioning of society in its entirety. Is the process of severe inequality reversible? We would like to respond in Mervyn King's words (2016): Maybe, with the audacity of pessimism.

\section{References}

Calhoon, C. (2015). Care sunt în prezent amenințările la adresa capitalismului. In I. Wallerstein, R. Collins, M. Mann, G. Derlugian, \& C. Calhoon (Eds.), Are capitalismul un viitor? Bucharest: Comunicare.ro Publishing House.

Dalton, P. S., Ghosal, S., \& Mani, A. (2015). Poverty and aspirations failure. The Economic Journal, 126(590), 165-188.

DeLong, B., Boushey, H., \& Steinbaum, M. (2017). Introduction. Capital in the twenty-first century, three years later. In H. Boushey, J. DeLong, \& M. Steinbaum (Eds.), After Piketty: The agenda for economics and inequality. London: Harvard University Press.

Ermisch, J., Markus, J., Smeeding, T., \& Wilson, J. (2012). Advantage in comparative perspective. In J. Ermisch, M. Jäntti, \& T. Smeeding (Eds.), From parents to children (pp. 3-31). New York: Russell Sage.

Georgescu, F. (2017). Creșterea economică, dezvoltarea României şi reducerea sărăciei [Economic growth, Romania's development and reducing poverty]. Accessed November 11, 2017, from http://www.bnr.ro/Prezentari-si-interviuri\%2D\%2D1332.aspx?fld_issue_year=2017 
Graham, C. (2017). Happiness for all? Unequal hopes and lives in pursuit of the American dream. Princeton, NJ: Princeton University Press.

Jerrim, J., \& Macmillan, L. (2015). Income inequality, intergenerational mobility, and the Great Gatsby Curve: Is education the key? Social Forces, 94(2), 505-533.

King, M. (2016). The end of alchemy, money, banking and the future of the global economy. London: Little, Brown.

Krueger, A. (2012). The rise and consequences of inequality in the United States. Remarks for the Center for American Progress. Accessed March 12, 2018, from http://www.whitehouse.gov/ sites/default/files/krueger_cap_speech_final_remarks.pdf

Lagarde, C. (2015). Lifting the small boats. Address at Grandes Conferences Catholiques, June 17, 2015. Accessed March 26, 2018, from https://www.imf.org/en/News/Articles/2015/09/28/ $04 / 53 / \mathrm{sp} 061715$

Milanovic, B. (2016). Global inequality: A new approach for the age of globalisation. Cambridge: Belknap Press of Harvard University Press.

Obama, B. (2016). The way ahead. The Economist, October 8th, 2016. Accessed April 18, 2018, from https://www.economist.com/news/briefing/21708216-americas-president-writes-usabout-four-crucial-areas-unfinished-business-economic

Piketty, T. (2014). Capital in the twenty-first century. Transl. Arthur Goldhammer. Cambridge: The Belknap Press of Harvard University Press.

Pope Francis. (2016). An economy of exclusion and inequality, May 13, 2016. Accessed March 15, 2018, from http://www.osservatoreromano.va/en/news/economy-exclusion-and-inequality

Zamfir, C (Ed.). (2017). Starea socială a României. Calitatea vieții: situația actuală şi perspective pentru 2038. Special Report of the Research Institute for the Quality of Life in Romania.

\section{Online Sources}

The State of the nation. The development of an innovative instrument for grounding the development of public policies in Romania. Accessed April 12, 2018, from http://starea-natiunii.ro/ index.php/en/

Open Access This chapter is licensed under the terms of the Creative Commons Attribution 4.0 International License (http://creativecommons.org/licenses/by/4.0/), which permits use, sharing, adaptation, distribution and reproduction in any medium or format, as long as you give appropriate credit to the original author(s) and the source, provide a link to the Creative Commons licence and indicate if changes were made.

The images or other third party material in this chapter are included in the chapter's Creative Commons licence, unless indicated otherwise in a credit line to the material. If material is not included in the chapter's Creative Commons licence and your intended use is not permitted by statutory regulation or exceeds the permitted use, you will need to obtain permission directly from the copyright holder.

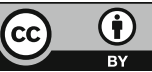

